\title{
Parochial Political Culture: The Bane of Nigeria Development
}

\author{
Rosemary Anazodo (Ph.D) \\ Department of Public Administration \\ Nnamdi Azikiwe University, Awka. \\ E-mail:Rosyzodos@yahoo.com \\ Agbionu, Tina Uchenna \\ Department of Business Administration \\ Nnamdi Azikiwe University, Awka, Nig \\ E-mail:uctina@yahoo.com \\ Ezenwile Uche \\ Department of Public Administration \\ Anambra State University, Uli \\ Anambra State
}

\begin{abstract}
This paper examined the effect of parochial political culture on national development in Nigeria. It is imperative at this time more than any other in the history of Nigeria, a country at crossroad to vigorously address the challenges posed by the parochial political culture, without which political stability, political innovation, national development among others would be a mirage. For many decades Nigeria has been on a steady decline in regards to all indicators of national development. On this premise the paper intends to investigate how Nigeria's political culture impedes her national development. Based on the assertions above, some objectives were formulated to guide the study. Theories of two republics and Prebendalism formed the basis of the study. Some findings were made and recommendations provided on the way forward.
\end{abstract}

Keywords; Parochial, Political Culture, Development.

\section{Introduction}

Nigeria is sadly at the other side of political and economic development. Annual income per head is dismally low, economic and social infrastructures are underdeveloped and manufacturing base is weak. 
Nigeria is a rich country whose economy has been mismanaged over the years. The excellent investment opportunities have been affected by unstable political atmosphere and threats to security of life and property (Abimboye, 2010:18). Nigeria has been crawling development wise when it should be running fast after her independence. President Jonathan saw the failure of leadership as the greatest obstacle to the desired growth-political and economic.

This statement falls in line with the views of those Western European leaders of the 1930's who believed that the economic system would be favourable if only earnest and God fearing men are in command of its destinies.

Nigeria is yet to witness much development after half a century of her political independence, and this is attributed to the occupation of sensitive state offices by a crop of visionless men and women who are only concerned about how to appropriate and grab collective wealth for personal aggrandizement.

The state is basically constituted for the development of its citizens. In the area of economic, the state performs the following functions; policy formulation, provision of infrastructure. education, vocational, moral and political, creation of enabling environment for investment and economic growth, provision of employment opportunities, mobilization of patriotic spirit, direct involvement in enterprise etc.

The role a state plays in economic development and how it plays it are determined by the prevailing economic, political ideology and political culture in the state among other factors. The fact that majority of Nigerians live below poverty level in a society so blessed by natural resources amount to monumental injustice, and failure of leadership. This is however possible because of the kind of political culture practiced in Nigeria.

There are three basic political cultures known to social scientist and each has its peculiar attributes. The type of political culture practiced in Nigeria is the parochial political culture which consequently breeds 
what Dike (2006) termed instrumental leadership. Most of the leaders are mired in the pursuit of selfish and personal goals at the expense of broader national interests. Most governments all over the world understand and appreciate the importance of development and its sustainability. In Nigeria due to the type of political culture practiced, the leaders are what Apter (1960), aptly brands "Consumetory leaders". They use official power and influence primarily in the pursuit of private goals. To the leaders, the national objective is very secondary as they are merely concerned about how to use official position to achieve personal objectives. This is possible because the citizens are not fully aware of the input/output processes of the political system

However the leaders may not be lacking completely in social or community commitments but overall more considerations are given to self than interest of the society (Eulau, 1963 in Dike, 2006) without minding the disruptive impact. Nigerian leaders like "absolute power" and usually hold on to power as long as private objectives are achieved (Kofele0Koale 1976). Because of the type of political culture in Nigeria, and because the citizens lack knowledge of what the government should be doing for them, they expect little or nothing from the government. They are not interested in what happens in the political system and so the leaders loot the treasury and make policies that are to their own advantage. The masses through socialization(political culture) have come to internalize the norms of respect for authority. They find it very difficult to challenge or criticize authority. Political office holders insist on being treated as tin-gods even when they are not performing. The norm in Nigeria is; if the behaviour of the incumbent leader is similar to that of the past corrupt and ineffective leader some citizens take it as a usual and normal behaviour and would not press for change. This paper therefore seeks to examine the effects of parochial political culture on the social and economic development of Nigeria.

\section{The Problem}

Nigerian leaders since Independence have so impoverished the country that her social and economic institutions have virtually collapsed.They embezzle public funds with impunity due to weak or the absence of effective institutional checks and balances. Nigerian leaders take undue 
advantage of these shortcomings to circumvent the few institutional restraints put in place to loot the treasury. They get involved in grand corruption and acquire wealth through questionable means which they use to bribe their ways to remain in power for life. Nigeria has not developed fully because the society had been according undue and undeserved respect to public officials and political office holders. Our leaders are fraudulent and opportunists who are so selfish to the detriment of overall national interest. No wonder, Professor Chinua Achebe reiterated that the problem of Nigeria is simply and squarely that of failure of leadership. Garner (1976), agreeing with Chinua Achebe affirmed that no society can function well with fools, rascals, or non leaders in leadership positions. That is the crux of the matter and the course of unending religious and social conflicts in the country. Some of the Nigerian leaders lack the integrity and knowledge to perform their national duties. According to Samuel Johnson "integrity without knowledge is weak and useless and knowledge without integrity is dangerous". All of the above and more are responsible for the decayed infrastructure, down turn in our economy, political and social conflicts and general lack of development and sustainability in Nigeria. This paper therefore sought to examine the Empirical and conceptual effects of parochial political culture on national development in Nigeria.

\section{Objectives of the Study}

This paper therefore intends to;

1. Discuss parochial political culture and its effect on development in Nigeria.

2. Link leadership question to parochial political culture

3 Examine the dimensions of corrupt practices in Nigerian institutions.

4. Investigate the consequences of corruption on national development

5. Make recommendations on the way forward.

\section{Parochial Political Culture and Its Effect on Development in Nigeria}

The type of political culture practiced in Nigeria accounts for lack of interest and commitment on the part of the citizens towards what is 
happening in their political arena or the political environment. This is because culture shapes and influences social action.

Lack of orientation of Nigerians towards the political system has caused the country sustainable national development; and absolute lack of commitment. This was evident when President Olesegun Obasanjo was in power. The leaders capitalize on the people's lack of interest in what is happening in government to deny the country a systematic and sustainable development. They are instead busy amassing wealth for their personal gain, and this accounts for the high level of corruption, ineptitude and lack of political direction which have inhibited the country's growth, development and the attainment of the Millennium Development Goals (MDGs).

It is most evident, when you place Nigeria in juxtaposition with other countries like U.S.A and Britain where participant and subject political cultures are practiced, respectively.

Parochial political culture shapes and influences social action in Nigeria and consequently determines it. A good example is the issue of bribery for contracts involving some Nigerian leaders and multinational firms. In America, the people who were involved in the scam had since been brought to book, but in Nigeria, none of the people whose names were mentioned in the scam had been interrogated let alone jailed. As a matter of fact, anti graft agencies whose duty is to bring these people to book (EFCC, ICPC, etc.) were busy sweeping the grievous offence under the carpet without batting an eye lid, simply because of the caliber of people involved in the scam. Nigeria citizens on their own part are non-challant towards the scam. They had not in any way agitated or even ask questions about the deals. Today, some of the people involved in the scam are presently flagging off campaigns and rallies for elections come 2015. This indicates the level of awareness of the people in the political affairs and development of their nation.

The system is corrupt, so also the leaders because they are part and parcel of the corrupt system. Leadership behaviours do not often seem to be directed towards achievements of the welfare of the people and 
progress of the nation. Wealth and socio-economic status have become the precursor of Nigeria leadership and nobody cares to ask questions on how the wealth has been acquired. People therefore, pursue wealth without any qualms of conscience. Public treasuries are looted with impunity; donations are given in millions of naira, the donors receive accolades from all and sundry, even from the governments; chieftaincy titles flow from all corners. This accounts for lack of vision and mission in Nigerian leadership style and that is why effective leadership is as rare in Nigeria as a British falcon.

According to World Report (2008), the Nigerian leaders have so impoverished the nation that people find it very difficult to feed at least twice a day. People are dying of hunger, disease and wallow in abject poverty. If all the monies stolen by these leaders were ploughed back into the education and health sectors, Nigeria would have been better for it (Transparency International 2010).

The question is; can Nigerians ever enjoy good roads, good health, pipe borne water, and other facilities? Can she ever attain Sustainable National Development with this type of attitude and orientation towards the political system?

\section{Corruption in Nigeria's political Institutions}

There is no gainsaying the fact that corruption is a social malaise that is not unique to Nigeria. However, what makes this cankerworm egregiously unique to Nigeria is that it is pervasive, it is endemic, it is pandemic, and it is seemingly intractable.

Corruption has eaten so deep into the fabric of our society, that no segment can claim immunity from its ugly effects, not even religious bodies, (Agenda 20:2020). For example, a communique issued by the Christian Association of Nigeria (CAN) at the end of its $6^{\text {th }}$ National Assembly in 2006 captured the endemic problem of corruption as follows:

Corruption today is still a deadly disease in Nigeria. Corruption has been responsible for the collapse of our economy, the infrastructure 
and the collapse of Education and health sectors and other areas of life. Many Nigerians are yet to be free from it....

(Christian Association of Nigeria, 2006)

Corruption is present in all sectors of our society, more especially in the government institutions, the Executive Arm, the Legislative Arm (the Senate, House of Representative), Local Governments, the judiciary (courts, tribunals, lawyers), and uniformed establishments (Military, police and road safety corps) etc for emphasis sake, see table below:

Comparative Assessment of levels of corruption in Nigeria Institution (scale: $1-5$ )

\begin{tabular}{|l|l|l|l|l|}
\hline Institution/Agency & $\mathbf{2 0 0 4}$ & $\mathbf{2 0 0 5}$ & $\mathbf{2 0 0 6}$ & Rank \\
\hline Police & 4.8 & 4.7 & 4.9 & 1 \\
\hline Political Parties & 4.5 & 4.5 & 4.5 & 2 \\
\hline Customs & 4.0 & 4.2 & 4.2 & 3 \\
\hline Legislature & 4.2 & 4.1 & 4.1 & 4 \\
\hline Educational System & 3.8 & 3.8 & 4.3 & 5 \\
\hline Judiciary & 3.8 & 3.8 & 4.1 & 6 \\
\hline Military & 3.9 & 3.8 & 3.7 & 7 \\
\hline Utilities (PHCN etc) & 3.5 & 3.6 & 3.8 & 8 \\
\hline Tax Revenue & 3.8 & 3.6 & 3.5 & 9 \\
\hline Business/Private Sector & 3.4 & 3.2 & 3.7 & 10 \\
\hline Registry Licensing (CAC, etc) & 3.3 & 3.1 & 3.3 & 11 \\
\hline Medical Services & 3.1 & 3.0 & 3.4 & 12 \\
\hline Media & 3.0 & 2.8 & 3.2 & 13 \\
\hline NGO's & 2.7 & 2.5 & 3.0 & 14 \\
\hline Religious Bodies & 2.4 & 2.3 & 3.0 & 15 \\
\hline
\end{tabular}

Source: Agenda 20:20:20; Redesigning Nigeria's future, p:21

In a thought provoking expository study on the content of corruption in Nigeria, Daniel Smith (2007) focuses on the pervasive culture of corruption that manifests in forms of deception and malpractice that come to tragically symbolize the nature of the Nigerian State and political culture. 
The most disturbing are the recent Halliburton, Siemens, and Wilbros scams which involved some of our past executive leaders, some members of the National Assembly and some top government officials. So also is the recent bank crises which were caused by some corrupt chief executives of banks. Let us now look at the scams one after the other;

Halliburton Scam: This scam dates back to 1994 when some foreign companies put up bids for the construction of the plant that was to cost \$6billion. To win the contract, a joint venture company, named TSKY, was set up comprising equal holdings between some companies. The firms are Technip (French) KBR (American) and part of the Halliburton group and Japanese engineering and construction company (JGC) (Transparency International 2010). Investigation into the matter revealed that the consortium bribed some political leaders and top government functionaries through Tri-star investment limited and marubeni incorporated. It also revealed that the group recruited Tesler and chodan to coordinate the scam.

The scam became a public issue when George Krammer, a former director general of the French company, technip was accused of paying three million euros in illegal commission during investigations into ELF-Aquitane operations in Asia and Africa. Mr. Krammer owned up to the commission paid, which according to him was the "cultural arrangement" (Abimboye 2010:12-20). In fact those mentioned in this scam were mainly our former heads of state and some top government officials. The list included President Ibrahim Babangida, General Sani Abacha, Ernest Shonekan and Abdulsalam Abubakar, Maryam Babangida; Maryam Abacha, Ibrahim Abacha, Mike Akhigbe, Orji Uzor Kalu, Anthony Ukpo, Samuel Ewang, Oladipo Diya, Atiku Abubakar and other top government functionaries. They shared the sum of N27 billion Halliburton loot. One common denominator held these people together and that is, they had served Nigeria in one capacity or the other.

During President Yar'adua's tenure he constituted a panel of inquiry to investigate the matter. The chairman of that panel former Inspector General of Police Mike Okiro submitted his report, but his report was 
never allowed to see the light of the day. One disturbing thing about this is that while American Government and other Governments whose citizens or officials were involved in the loot were busy jailing those found wanton, Nigeria was busy shielding those who shared N27 billion of public fund. It is incredible, considering what this money would have done to our economy. Surprisingly, some of those named in this scam are still vying for the highest position in our country and nobody cares to ask questions. One can not blame them because the level of awareness toward what happens at the center is very low, but this attitude has sacrificed development on the altar of perpetual poverty in the country.

\section{Corruption in the National Assembly}

National Assembly is an arm of government charged with the responsibility of making law. It consists of two chambers, the upper legislative chamber called the Senate and the lower legislative chamber called the House of Representative. The members of these two houses were elected by the people to represent them as much as possible and equally attract development for their communities.

In Nigeria that is in dire need of development, one expects the Legislature to offer quality representation that will affect the lives of Nigerians positively. Unfortunately, the reverse is the case, instead of working for the people that elected them; they are busy enriching themselves to the detriment of the masses.

Between 1999-2003 each member of the House of Representatives got N10million for a quarter, thus, in a year, each of them netted N40million. Presently, each member of the lower chamber nets N27.5 million as quarterly allowance or N110 million per annum. Yet the sum could be raised up soon to N42million per quarter or N168million yearly as demanded by the legislators. (BBC News, 2008).

Investigations have revealed that between 1999 and 2010, a total recurrent and capital allocation to National Assembly from the annual budgets stood at N712.8 billion. (Tobs, 2010:17) These exclude supplementary allocations within the period. In 2007, when the former 
set of lawmakers came in, N48.76 billion was allocated to the National Assembly from a total federal budget of N2.39 trillion. This, however, was disproportionately increased to N106.6 billion, made up of N5.25 billion capital expenditure and N101 billion recurrent expenditure in the N3,1018 trillion 2009 package. In 2010, a total of N154.205 billion out of N4.6 trillion 2010 package was provided for the National Assembly. This is made up of N138.015 billion recurrent and N16.9 billion capital expenditure (Tobs, 2010:14).

From 2007 to date, each sub-head of the annual National Assembly budget has been an example of padding and over loading and in many cases duplication, for instance, the 2007 allocation to the senate had 55 sub-heads or classifications. These ballooned to 74 in 2010. The 2010 House budget has 67 classifications. The late President Yar'adua proposed to spend N2.4 trillion in 2008; the legislators raised it to N2.89 trillion to take care of their interest. (AIT News 2010) Yar'adua refused to ascent to the bill, but after serious arm-twisting, he signed a revised N2.7 trillion version. In 2008, the President submitted N2.87 trillion this again was raised up to $\mathrm{n} 3.108$ trillion.

The members of the National Assembly allocated N5.06 billion to local and international travels, $\mathrm{N} 2.28$ billion to contingency vote, N1.259 billion to security sub-head and N3.68 billion materials and supplies.

According to World Report (2009), the Revenue Mobilization Allocation and Fiscal commission, RMAFC, charged with determining the salaries and allowances of public officials, put the annual basic pay of the Senate President at N2,484,345.50 his deputy at N2,309,166.75 while each senator receives N2,026,200 per annum. The Speaker of the House of Representative receives N2,477,110, his deputy N2,026,400 while floor members collected N1,985,212.50 per annum.

However, it was disclosed that senators approved a different salary for themselves which was different from the one approved by RMAFC. The total salary per senator per annum is thus $\mathrm{N} 29,479,772$ or $\mathrm{N} 2,456,647.70$ per month. Annually, all 109 senators take home N3,264,329,264.10. 
These allocations appear not to be the legislator's major avenue for income. Many of them often force ministries, departments and agencies they oversee to cough up huge amounts lest unfavorable reports are written on them (a case in point was Prof. Fabian Osuji's Saga) and many more like that (Ajaero 2009:21).

It was also revealed that the house committee on privatization and commercialization in 2008 rejected the good gestures of Nigerdock Nigeria plc to offset the legislator's airfares to the tune of N400,000. But they rejected the "paltry sum", with one of them saying "we talk in billions. If you make it $\$ 20$ million (about N2.5 billion), fine”. The company refused to accede to the legislator's illegal request. Two years after the incident, the committee has continued to discredit the company's efforts in overhauling the moribund shipbuilding and repair yard. No wonder the lawmakers now live above their approved income, many own properties in Abuja and other choice areas in Nigeria to the chagrin of the electorates. In fact one senator from Enugu State now flies in and out of his country home on chartered helicopter for fear of kidnappers, while many people in his constituency are dejected, abandoned and shabbily treated.

Recently, the former President Obasanjo decried the excess money at the disposal of these lawmakers that have been milking the tax payers dry. In response, the lawmakers have berated him and called him all sorts of names. This type of bazaar jamboree can not happen in America; in fact the salaries of these lawmakers can comfortably pay the salaries of members of the American Congress and President Obama.

Professor Pat Utomi (2010) in an interview granted to Newswatch Magazine summed up the rot in the National Assembly as,

Institutionalized corruption, in which a full time legislature foisted on the country. What Nigeria needs, is a citizen's legislature where professionals such as lawyers, engineers or doctors can take a few weeks off and come, make laws and return to their jobs. They should be paid about N10, 000 for their efforts.... The political class is consuming most of the resources. It is scandalous and the young 
people of Nigeria have not spoken. In other countries the streets would have been full until we change the institutional arrangement.

\section{Siemens Scam}

Siemens Nigeria Ltd is a German Company, operating in Nigeria that won the improvement of power transmission. Apart from this contract, the company had executed other projects like the 276MW Afam V power plant and the 130 Turnkey projects for Zain Nigeria.

The company had completed the first phase of the 414MW Power Plant and over 2,000 kilometers of $33 \mathrm{kv}$ and $11 \mathrm{kv}$ transmission lines for the interconnection of various towns and villages in Anambra, Imo, Borno, Adamawa, Taraba, Edo and Ondo States. Siemens had also designed and installed over 1000 kilometers of $132 \mathrm{kv}$ transmission lines throughout Nigeria from 1979 to date. More than 15 major $330 \mathrm{kv}$ and $132 \mathrm{kv}$ were also designed, and installed by Siemens for the Power Holding Company of Nigeria. (Africas Confidential, 1999:40).

From the above, it is obvious that Siemens Company is a well known company in Nigeria that has won a number of contracts. Unfortunately, many Nigerians did not know that these contracts were won without due process as the company bribed some Nigerians in their bid to win most of these contracts.

This was revealed by a Munich State Court that tried and found guilty two former Siemens Managers for breach of trust and abetting. Also the court placed them on probation Mr. Micheal Kutschenveuter, a former financial head of the Telecom unit was fined 160,000 euros. The former head of Accounting was placed on one and half year's probation and was fined 40,000 euros (BBC News: 2008).

The court indicated four former Nigeria Communication MinistersCornelius Adebayo, Late Haruna Elewi, Tajudeen Olanrewaju and Bello Mohammed, the former Permanent Secretary of the ministry, Senator Jubril Aminu, they were all accused of E17.5 million bribery scandal (Transparency Int, 2006). 


\section{Money Laundering by Some Political Leaders in Nigeria}

Some governors in Nigeria see political offices as a means of enrichment instead of service to the people. The most recent case is that of the former governor of Delta State (James Ibori), who was accused of using the money meant for the development of the state for his personal enrichment. It was discovered that the former governor fraudulently sold the Delta State government's 528 million shares in Oceanic Bank to guarantee over N44 billion facilities granted Ascot offshore Nigeria limited by intercontinental bank. Unfortunately this loan acquired could not be paid and when the Central Bank of Nigeria made their startling revelation, it was discovered that Ascot offshore Nigeria limited had not paid the N44billion borrowed from Intercontinental Bank. Ascot offshore Nigeria Limited is one of the companies of the said governor. Again, some foreign security agencies working with Economic and Financials Crime Commission discovered that the former Governor was involved in false pretence, stealing and money laundering. In fact one investigator says that the governor's looting of the state he governed was so brazen and widespread that it would be impossible to discover all his atrocities for many years. (Akintunde 2010:12-17). When Economic and Financial Crimes Commission invited him over the matter, he went into hiding instead of submitting himself to the commission; he sought for protection from the youths of his village, the very people that he defrauded. These youths, it was revealed were ready to die in their bid to protect their master. These were monies meant to develop the State and equally empower the youth, but these youths were not bothered that most of them were not in school, in good job and could not even have access to quality health care.

The said governor was outside the country enjoying his loots and EFCC and other corrupt agencies are mere spectators in the job for which they were paid to do. However presently in 2012 the said governor was found guilty of money laudering by the British government had since been jailed to serve 14 years term. (AIT News 2012). Others are Aleiyemesia of Bayelsa state, president Sanni Abacha of blessed memory etc The list of Nigerian leaders who have defrauded the nation is endless. The above is just few examples out of many. 


\section{Cnsequences of Corruption on National Development}

The personalist monopolization of state power has direct link with the political culture of the nation. Since independence in 1960, Nigerian leaders have formalized the culture of corruption, and in recent years it has become an endemic culture of social impropriety in the country. Thus, Osaghae (2008) referred to the corrupt officials as "Corruption soaked elites. Government corrupt practices in Nigeria include both formal (bribery, looting of state treasury, over invoicing of contracts, illicit sale of oil blocks and bureaucratic salary fraud etc), and informal corruption tagged " 419 " in Nigeria, including; extortion, culture of impunity, oil theft and bunkering, pay off to political thugs by political god-fathers etc (HRW,2007:31). This formalized culture of corruption has in recent years included legislative bills and litigation involving financial considerations, put plainly as bribes. This argument is captured by Garba that "the fight for booty" or "national cake" is fierce and often vicious. It has at times led to a debilitating corruption in the arena of public policy formulation and implementation. The consequences of which are; decaying infrastructure, bad road network, poor health care institutions. The result of which is the soaring rate of accidents on our roads and health centers which have turned into slaughter slabs for poor citizens.

Every year, huge sums of money are budgeted for the construction of roads and its maintenance but the money usually disappears into few pockets. The health sector is in a deplorable state, infant and maternal mortality are in the increase, hospitals are not well equipped, doctors go on strike on frequent basis because of lack of commensurate take home salaries, drugs are in short supplies etc (Sun Magazine, April, 2008). The education sector is worst for it. Lecturers go on strike because of poor remuneration and usually, it is the students and parents that suffer it. In the course of the lecturers trying to drive home their points, the students wallow on the streets and indulge in all sorts of nefarious behaviours.

Meanwhile, the Millennium Development Goals which the Federal Government of Nigeria is echoing on daily basis (gender equality, women empowerment, reduced child mortality, maternal healthcare, 
reduced hunger and disease, education for all, environmental sustainability and global development partnership by the year 2015) is fast becoming a mirage (World Report 2009). Nothing is seen done on ground despite the fact that Nigeria gets about N150 billion debt relieve annually from the Paris Club and additional N110 billion annually in the past six years to service the Millennium Development Goals (MDGs). Yet all these monies go down the drain in private pockets of our leaders and public officials without the people holding the culprits responsible. The fact that majority of Nigerians live below poverty level in a society so blessed with natural resources amount to monumental injustice and failure of leadership culminating in low national development.

\section{Conclusion}

It is evident that the political culture of a country affects its practices. However, the type of political culture practiced in Nigeria has robbed it of its national development. We therefore conclude that Nigeria's date with destiny has been put on hold because of the citizen's attitude towards the political system and the leadership behavior towards what they should be doing for the citizens for overall development of the country.

Nigeria is a rich nation, it has all potentials for greatness, it is a nation blessed with vast natural and human resources, but its political culture and corrupt attitude of the leaders have forestalled its match to greatness and sustainable development.

If the amount of illegal resources acquired by those at the corridor of power is ploughed into some key sectors of the economy like education, health, agriculture, human capital development, infrastructure and power, the nation would have been rated among the most developed countries of the world.

\section{Recommendations}

The researchers recommend the following as a way forward for improving Nigeria's sustainable national development. 
1. The citizens should be re-oriented on the importance of participation both at the input and out-put stages of policy making.

2. The focus of all economic policies and actions should be directed

towards the people's welfare and well-being.

3. Stringent punishment should be put in place for public office holders who abuse their positions and made to realize that they were elected into power to serve and not to impoverish the people

4. Any government official that is found wanting when he/she is still in power should be called back even after leaving the office to give account of his/her stewardship and appropriate punishment meted to the offenders.

5. Nigeria should evolve a political culture that will be people oriented in line with its peculiar needs and aspirations.

\section{References}

Abba, U.E, and Anazodo, R. O. (2006) Development Administration in Africa Onitsha: Abbot Books Ltd.

Abimboye, D. (2010) “A Nation Unbearable Burden” Newswatch, July 12, pp 12-20.

Africa's Confidential Nigeria Lousy Legacies' Vol 40 no 243 December, 1999.

Agenda 20: 20: 20 "Redesigning Nigeria's Future” Association of National Accountants of Nigeria. Lagos

Ajaero C. (2009) “Roads to Hell”, Newswatch, December 28, pp12-21 
Akintunde, K (2010) “Ibori's Dubious Court Victory”, Newswatch, September, 20 pp. 12-17

Almond, G and Verbe. S. (1995) _ The Civil Culture. Boston: little brown and company.

Anazodo, R.O (2004) Issues on Political Culture. Unpublished Research Work. Department of Public Administration. Nnamdi Azikiwe University, Awka.

BBC "Fraud Ring Uncovered in Nigeria" at www.News.bbc.co.uk/I/hi/World/Africa accessed on the 21 of April, 2008.

Economic and Financial Crime Commission: EFCC Official Website at www.efccnigeria.org accessed on the 19 of April, 2009.

Elazar, D (1972) American Federalism. A view from the States $2^{\text {nd }}$ edition New York: Thomas Y Crowell

Feiock, R.C and Adams, S.C (2003), Sustainable Development Encyclopedia of Public Administration and Public Policy(ed) (P.1169); New York: Marcel Dekker, Inc. http://www.Allacademic.com/metalp.253601

Human Rights Watch (2008), "Nigeria”. World Report, New York, pp $137-143$

Leadership Newspaper (Lagos $3^{\text {rd }}$ June, 2008) "Nigeria Loses

$\mathrm{N} 3.5$ trillion to corruption"-at www.allafrica.com accessed on 09/07/08.

Nnoli O. (2003) Introduction to Politics. Enugu: PACREP

Nwankwo O.B.C (2009) "Good Governance Matters of Development" in O.S.A Obikeze (ed), Dynamics of Public Sector Management in Nigeria (pp 17-27). Enugu: Rhyce Kerex Publishers

Okoye, J.C. (1997) Modern Management Techniques and Development Administration Onitsha: Abbot Books Ltd 
Olewa, B. N (1995) Development Administration, Aba: Grace Ventures

Pye L (1995) "Political Culture" in the Encyclopedia of Democracy, (ed), (pp 965-969). London and New York: Rout Ledge.

Rodney, N (1972) How Europe Underdeveloped Africa. Washington D.C: Panaf Publishing Inc.

Smith, D.J (2007) “A Culture of Corruption: Everyday Deception and Unpopular Discontent in Nigeria” Africa, No 77 (4), P. 608.

Szeftel, M. (2000.a), "Between Governance and Underdevelopment: Accumulation and Africa's Catastrophic Corruption" in Review of African Political Economy No 88 pp 287.

Tobs, A. (2010) “The Dream Threathened” Newswatch. August 20 pp $14-18$

Utomi, P. (2010) “Institutionalized Corruption”, Newswatch Magazine pp. 15 